\title{
The lake deposits in Płock Basin (case studies of Lakes Rakutowskie and Żłoby)
}

\author{
Andrzej Harasimiuk, Bogumił Wicik, Tomasz Grabowski \\ University of Warsaw, Department of Geoecology, Faculty of Geography and Regional Studies, \\ Krakowskie Przedmieście 30,00-927 Warszawa, Poland, e-mail: A.Harasimiuk@uw.edu.pl
}

\begin{abstract}
Reconstruction of development of Lakes Rakutowskie and Żłoby in the late Pleistocene and Holocene was the aim of this research. Analysis of content of calcium carbonate, organic matter and C14 datings (7 samples) were done for two cores of sediments of $750 \mathrm{~cm}$ long. An average rate of accumulation was counted. Sediments of Lake Rakutowskie show homogeneity along the core which indicates similarity of sedimentation conditions. Sediments of Lake Żłoby were diversified and show variety related to cyclic changes. A common feature is a thick layer of fine sand without carbonate deposited during the older dryas, shown in both cores. The difference in sediment features of both lakes (which have similar depths) indicates that the Lake Żłoby is the more dynamic, filtering element, preceding Lake Rakutowskie in system of water catchment.
\end{abstract}

Key words: lacustrine deposits, Płock Basin, limnochronology, lake geoecosystem

\section{Introduction}

The investigation of lakes deposits enables to reconstruct history of processes and environmental conditions in local and regional basin of sediment supply. Additionally several conclusions and predictions of future behavior of lake and its surrounding areas are possible to infer. That kind of investigation is especially important in case of protected areas, when the strategy of protection aims at conservation of the state of equilibrium of geoecosystems. In lake geoecosystems water conditions are the main factor affecting other elements of geoecosystems such as biota and sediments. Under feedback conditions, lakes deposits play significant role in process of evolution of lake basin and back on water conditions. Based on lake deposits analysis it is possible to determine the recent stage of geoecosystem evolution. In this paper case study of deposits Lakes Rakutowskie and Żłoby is discussed.

\section{Methods}

The lake deposits from the Lakes Rakutowskie and Żłoby were sampled using a piston corer of Więckowski construction (Więckowski 1959). The field work was performed in the winter season of 2006 (March) and the core samples were collected from the ice surface of the frozen lakes. The coring points were situated in central parts of the lakes, at the water depth nearly $2 \mathrm{~m}$. The corer was passed through sediments of the lake deposits and reached underlying sandy material. The collected deposits were continuous and complete, with non-damaged structure. After the cores were cleaned, notes were taken based on visual examination and then they were transported to an analytical laboratory for further investigation. After drying, the carbonates content and loss of ignition were determined. The cores from both lakes were divided into several segments of the following lengths: $2 \mathrm{~cm}$ length (starting from the top to $2 \mathrm{~m}$ depth of deposits) and $5 \mathrm{~cm}$ length (from the $2 \mathrm{~m}$ depth to the bottom of deposits; nearly $7.5 \mathrm{~m}$ depth). Over 350 samples were prepared this way for laboratory analysis. The carbonates were determined by Scheibler method and the 
loss of ignition was detected at $550^{\circ} \mathrm{C}$ (Ostrowska et al. 1991). The samples from several sections, which were believed to be important based on preliminary visual examination, were sent to radiocarbon C-14 determination (Radiochemistry Laboratory, Archeological and Ethnographical Museum in Łódź). The dates were calibrated (atmospheric data from Reimer et al. 2004; OXCal v3.10 Bronk Ramsey 2005)

\section{Study Area}

The Lakes Rakutowskie and Żłoby and their surrounding areas are of very magnificent natural heritage. They both constitute very well known rare waterbird habitats within European range. In the surroundings of the lakes natural preserve "Olszyny Rakutowskie" with valuable alder and ash forest (Carici elongatae-Alnetum, Ribo nigri-Alnetum, Sphagno
squarrosi-Alnetum and Circaeo-Alnetum) was established. Both lakes are located in Płock Basin, $8 \mathrm{~km}$ south of the Lake Gościąż, which is a well-recognized reference site in paleoecological investigation of Holocene history. The Lake Gościąż and the lakes of the system Rakutowskie-Żłoby have noticeable similarity of their hydrological conditions. Both lakes - Rakutowskie and Żłoby are flow type of lakes. The directions of the main axes of the lakes' surfaces are parallel to the Vistula River. Sandy, dune areas are separating the chains of lakes, as shown in Fig. 1. The Lakes Rakutowskie and Żłoby are located on the surface water discharge network. The direction of the water flow is from the Lake Żłoby toward the Lake Rakutowskie.

The water level of the Lake Rakutowskie is 71.0$72.3 \mathrm{~m}$ above sea level. Due to that the fact that the area covered by the lake water may double and may vary between 200 to 400 ha, the surrounding area

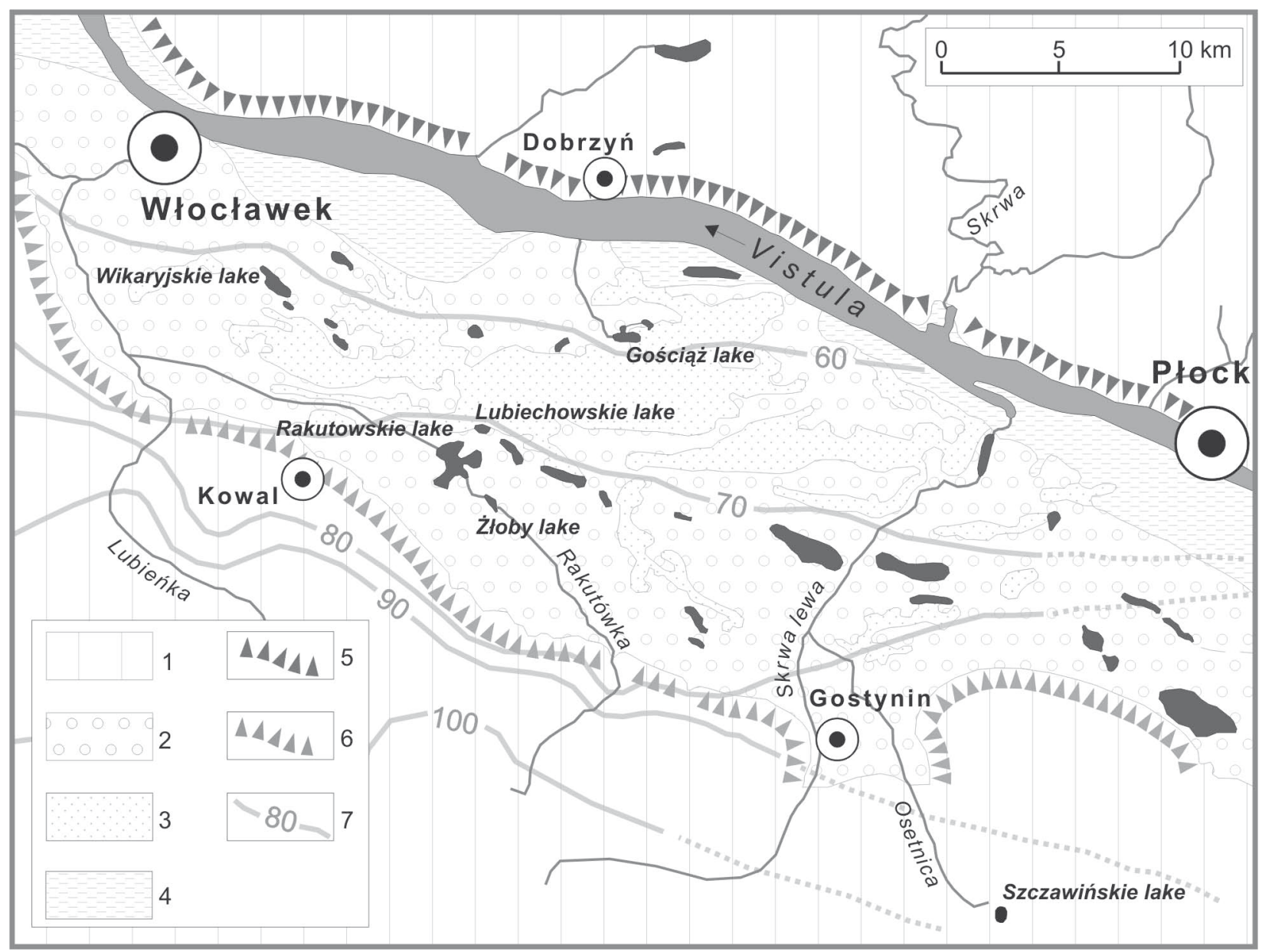

Fig. 1. Geomorphological sketch of Płock Basin (according to various sources): 1 - glacial plateau, 2 - fluvioglacial terraces, 3 - eolic sands and dunes (dune's area), 4 - fluvial terraces, 5 - steep edges of glacial plateau (= borders of Płock Basin), 6 - gentle edges of glacial plateau (= borders of Płock Basin), 7 - hydroizohypses 
of the Lakes Rakutowskie and Żłoby is periodically flooded. The Lake Rakutowskie is shallow - its depth usually does not exceed $2 \mathrm{~m}$. The marginal vegetation of this lake (the sedge meadows) on the border of the water and surrounding land has broad occurrence and is a few hundred meters wide.

The lake system is currently supplied by water flows coming from four different directions. The direction of the first water flow is parallel to the Vistulariver. The features of this water were formed under current conditions and are characterized by the lowest level of transformation caused by soil and mineral substratum. Second water flow is perpendicular to the Vistula-river, and supplied by surface waters from glacial plateau. Third - consists of ground waters in aquifer system connected with regional water system (see Fig. 1 - hydroizohypses). Fourth - deep underground water discharged through hydrological window.

\section{Results of the study}

The analysis of the deposits of the Lakes Rakutowskie and Żłoby provides important insights in explanation of Holocene and late-Pleistocene history of Płock-Valley. Although the lake sediments are not laminated, they have interesting changes of their chemical properties in the profiles. The length of the Lake Rakutowskie core is $785 \mathrm{~cm}$, the Lake Żłoby $735 \mathrm{~cm}$. The segmentation of the two cores is different within the depth and thickness of strata, but some parts of cores are correlated each other. Especially the top and bottom parts of the cores (organic deposits at the top and Pleistocene fine sands at the bottom) show observable similarities. This indicates that both lakes are parts of the same water system, but their different roles and locations in water runoff system are followed by differences in structure of these two lakes deposits.

The visual and analytical features of the cores' sediments allowed for dividing them into the following sections:

The simplified description of the Lake Rakutowskie deposits (Fig. 2) 0-80 cm - calcareous gyttja, grey-olivish color, gelatinous, weakly compacted;

$80-450 \mathrm{~cm}$ - calcareous gyttja, olivish color, compacted, with irregular single strata;

450-660 cm - calcareous gyttja, grey color, compacted; 660-731 cm - calcareous-detritus gyttja, grey-olivish color, with irregular strata;
731-745 cm - calcareous gyttja, grey-olivish color, with sandy material, at the bottom silty material;

745-756 cm - moss peat, dark brown color, undecomposed;

756-764 cm - decomposed peat, dark brown color; 764-785 cm - fine sand grey color.

The simplified description of the Lake Żłoby deposits (Fig. 2)

$0-50 \mathrm{~cm}$ - calcareous-organic and algal-calcareous gyttja, grey-olivish color, gelatinous, amorphic, single shelves at the bottom

50-428 cm - calcareous gyttja, grey-olivish color, compacted, single shelves in whole segment of profile; 428-499 cm - algal-detritus gyttja, olivish color, greyolivish color, compacted;

499-530 cm - silty calcareous gyttja, with sand, grey color, compacted;

530-536 cm - algal gyttja, grey-olivish color, weakly compacted;

536-644 cm - silty mineral-organic material, weekly laminated;

644-670 cm - algal-calcareous gyttja with fine sand; $670-696 \mathrm{~cm}$ - silt and sand material, with moss peat and small branches of shrub gyttja with fine sand; 696-735 cm - fine sand, grey color.

The results of analysis of chemical composition of the core deposits are shown in Fig. 2. A few of similarities and also a couple of differences can be observed in these two cores. The deposits of the Lake Rakutowskie is more invariable in the segment 0-11 800 BP $(0-630 \mathrm{~cm}$ - Lake Rakutowskie and 0-450 cm Lake Żłoby). The representation of the same time period in the Lake Żłoby is more differentiated, especially in calcium carbonate content, which varies from 60 to $85 \%$. The top of the core sediment $(0-80 \mathrm{~cm})$ of the Lake Żłoby is more organic (up to $40 \%$ of loss of ignition) in comparison to the Lake Rakutowskie (10-15 $\%$ of loss of ignition). The deposits, which had been accumulated between 11 800-12 000 BP of older dryas (Suffczyńska 2005: cited in Kozarski 1991) are more sandy, less organic and poor in carbonates in both lakes. In comparison to the Lake Gościąż reference (Wicik 1993) carbonate content in analyzed lakes are on the same level (20-25\%), but in the Lake Gościąż the process of sandy addition was not so strong. The Lake Gościąż is deeper than the analyzed lake system and the distance between this lake and glacial plateau is bigger (Fig. 1). Assuming that the material to the Lakes Rakutowskie and Żłoby was transported mainly from the local sources, mostly from the un-vegetated 

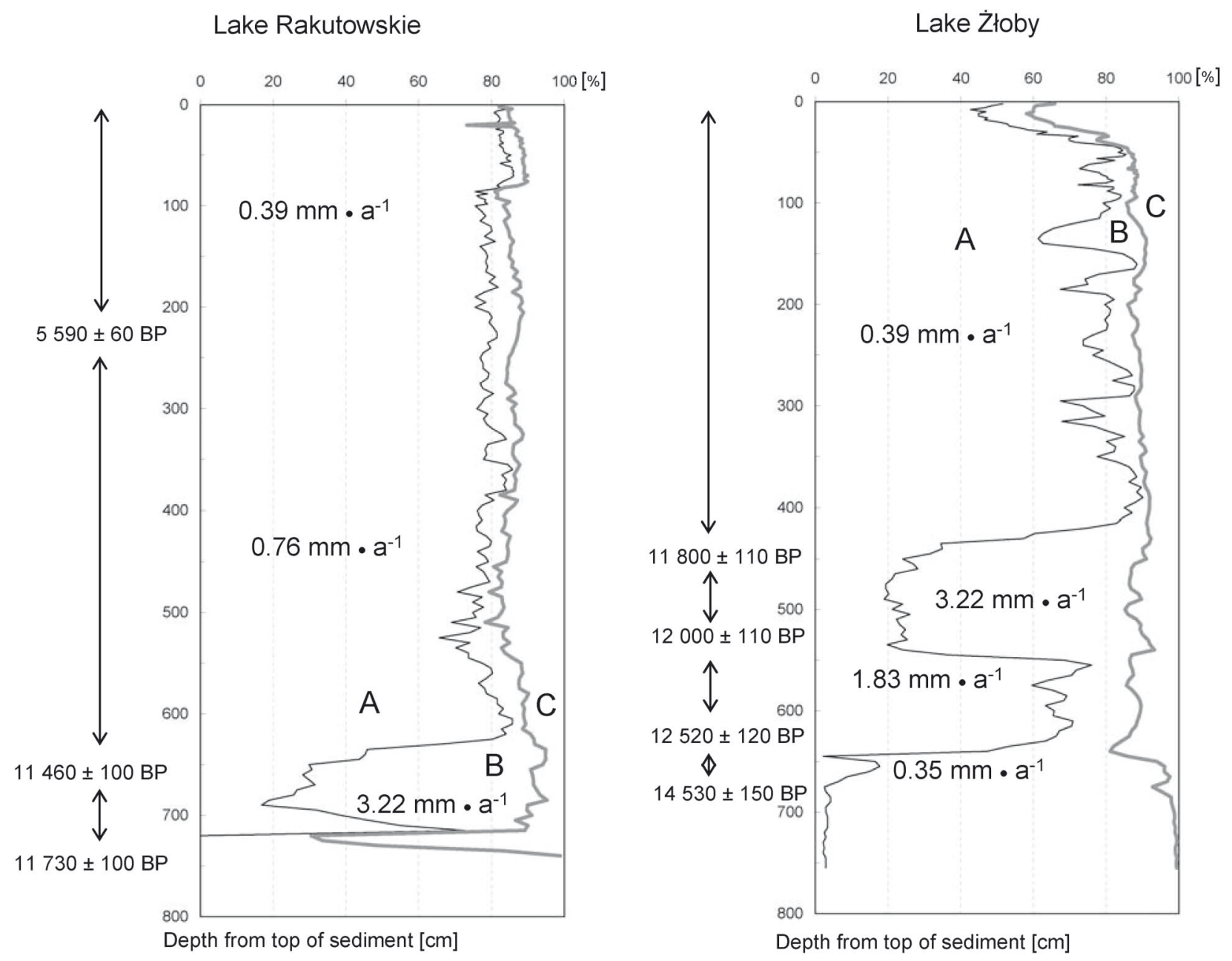

Fig. 2. Chemical composition of sediments shown at the background of age (BP) and annual rate of deposit thickness $\left(\mathrm{mm} \cdot \mathrm{yr}^{-1}\right)$. Explanations: A - calcium carbonate, $\mathrm{B}$ - noncarbonated inorganic material, $\mathrm{C}$ - organic material

glacial plateau then the deposits of these lakes, explain the differences in composition of deposits, and prove the significance of lake localizations in Płock Basin. The analyzed sandy episode observed in the sediment cores was of a sudden character. The annual rate of this sandy deposit growth was on the level of $3 \mathrm{~mm}$ per year and was nearly ten times faster then an average rate of deposit increase estimated on the basis of both cores (0.3-0.8 $\mathrm{mm}$ per year). The analyzed sandy strata from the Lake Żłoby core has more carbonate material with organic material at the bottom $(550-644 \mathrm{~cm})$ that could be referred to bölling period. The second sandy strata $(644-696 \mathrm{~cm})$ with the addition of tundra organic material could be referred to the oldest dryas. The oldest time data (14 $530 \mathrm{BP}$ ) was determined in the fine sand layer and indicates the accumulation event in the glacial period. The second reason for the older date is the addition of the old waters supplying the lake through a hydraulic window.

The time data 14530 BP (core Żłoby) corresponds to another lakes from Central Poland (Manikowska 1992; Więckowski 1993; Tobolski 1998) and leads to conclusion, that in core Żłoby are recorded processes from late glacial period. In the earlier accumulated deposits of the Lake Żłoby main properties of chemical composition have distinct cycle profile with differentiation in carbonate content. In the Lake Rakutowskie the profile is relatively stable and inorganic part of the sediment is built up by calcium carbonates (90-100\% of inorganic part of deposit). 
Taking into account that both lakes are located within the line of water flow, it can be concluded that the Lake Żłoby worked like a collective basin to which deposits were delivered, which contained the information of the processes occurring within the catchment area. In the Lake Rakutowskie, next on the line of the water runoff, sediments were accumulated in more stable conditions and its role is secondary comparing to the filtration role of the Lake Żłoby, so deposits in Lake Żłoby have not laminated features and deposits of Lake Rakutowskie are slightly laminated. The Lake Żłoby deposit has distinct periodical features connected with content of inorganic matter.

Additionally, this different role is clearly proved by type of the top of the core deposits - mostly organic in the Lake Żłoby (20-40\% of organic material) and much less organic in the Lake Rakutowskie (20\%). This is not exceptional situation. In deposit of Lake Żłoby is possible to observe few periods of distinct inorganic load, but the top of sediment is enriched also in organic matter. So large amount of organic addition (40\%) does not occur in any of lake in Płock Basin, including Lake Gościąż complex (Wicik 1993; Więckowski 1993). The catchment area of analyzed lakes is large, covered by semihydrogenous and hydrogenous (black earth, gley soils) and organic (peat soil) soils. In part of that area is located preserve "Olszyny Rakutowskie" with alder and ash forest. It is rest of larger forest area, reduced by deforestation processes. In conditions of plain relief erosion affected enriched in organic matter, surface soil horizons and Lake Żłoby play role of first collector and filter of transported organic material. Nowadays both of the lakes (Rakutowskie and Żłoby) are separated lakes, but earlier they could be part of broad Pre-Rakutowskie basin and Lake Żłoby was one of deep water parts. It can be concluded, that the top of sediments explains current trends and environmental preconditioning in functioning of this lake system and, as mentioned above, their different role in geoecosystem.

\section{Conclusions}

The deposits of the Lakes Rakutowskie and Żłoby prove unique role, different from Lake Gościąż in development of Płock Basin in late Pleistocene and Holocene. Regardless that the analyzed deposits in the Lakes Rakutowskie and Żłoby are not laminated, they have distinctive strata character by different composition of the material.
Especially the bottom of lacustrine sediment of the Lake Żłoby contains an interesting strata proving the event of forceful sandy addition of allochtonic material to the lake deposit.

The differences in the middle and top part of the core sediments of these two lakes explain their dissimilar roles in geoecosystem.

\section{References}

Bronk Ramsey C., 2005, OxCal progam v3.10. Online: http://www.rlaha.ox.ac.uk/O/oxcal.php.

Kozarski S., 1991, Paleogeografia Polski w Vistulianie (Palaeogeography of Poland in the Vistulian (Weichselian)), [in:] L. Starkel (ed.), Geografia Polski. Środowisko przyrodnicze (Geography of Poland. Natural environment), PWN, Warszawa: 80-105 (in Polish).

Manikowska B., 1992, Gleby kopalne w osadach z okresu 20 000-8 000 lat BP w Polsce (Fossil soils in sediments between 20000 and 8000 years BP in Poland), Prz. Geol. 10: 588-600 (in Polish).

Ostrowska A., Gawliński S., Szczubiałka Z., 1991, Metody analizy i oceny właściwości gleb i roślin (The methods of determination and assessment of soils and plants), Wyd. IOŚ, Warszawa, p. 334 (in Polish).

Reimer P.J., M.G.L Baillie, E. Bard, A. Bayliss, J.W. Beck, C. Bertrand, P.G. Blackwell, C.E. Buck, G. Burr, K.B. Cutler, P.E. Damon, R.L. Edwards, R.G. Fairbanks, M. Friedrich, T.P. Guilderson, A.G. Hogg, K.A. Hughen, B. Kromer, F.G. McCormac, S. Manning, C. Bronk Ramsey, R.W. Reimer, S. Remmele, J.R. Southon, M. Stuiver, S. Talamo, F.W. Taylor, J. van der Plicht, and C.E. Weyhenmeyer, 2004, IntCal04 terrestrial radiocarbon age calibration, 0-26 cal Kyr BP, Radiocarbon 46: 1029-1058.

Suffczyńska D., 2005, Geneza i rozwój rzeźby w czwartorzędzie (Genesis and evolutions of relief in Quaternary), [in:] A. Richling, K. Ostaszewska (eds) Geografia fizyczna Polski (Physical geography of Poland), Wyd. Nauk. PWN, Warszawa: 32-71 (in Polish).

Tobolski K., 1998, Późnoglacjalna historia zbiornika w Imiołkach (Late Glacial history of the Imiołki basin), [in:] K. Tobolski (ed.) Paleoekologiczne studium późnoglacjalnych osadów jeziora Lednica w Imiołkach. Lednicki Park Krajobrazowy (Palaeoecological studies of the Late Glacial sediments of Lednica Lake at Imiołki. Lednicki Landscape Park), Bibl. Stud. Ledn., 4: 69-76 (in Polish).

Wicik B., 1993, Chemizm wód i osadów jezior „Na Jazach” w Kotlinie Płockiej (Some chemical properties of waters and sediments of the „Na Jazach” lake complex in the Płock Basin), [in:] Jezioro Gościąż - stan badań nad osadami dennymi i środowiskiem współczesnym (Lake Gościąż - progress of studies on the sediments and recent environment), Pol. Bot. Stud., Guidebook Series 8: 93-104 (in Polish). 
Więckowski K., 1959, Pierwsze próby z sondą rdzeniową do pobierania monolitów osadów dennych jezior (A first attempt at obtaining monoliths of lake floor sediments by means of a core-sound), Prz. Geogr. 31(2): 361-366 (in Polish, English summary).
Więckowski K., 1993, Dotychczasowy stan rozpoznania osadów dennych jezior „Na Jazach” - cechy makroskopowe (The up-to-date state of recognition of bottom sediments in the „Na Jazach” lakes according to their macroscopic features), [in:] Jezioro Gościąż - stan badań nad osadami dennymi i środowiskiem współczesnym (Lake Gościąż - progress of studies on the sediments and recent environment), Pol. Bot. Stud., Guidebook Series 8: 77-92 (in Polish). 